\title{
Necrophagy of a nurse shark (Ginglymostoma cirratum) by tiger sharks (Galeocerdo cuvier)
}

\author{
Danilo P. Rada ${ }^{1 凶}$, George H. Burgess ${ }^{2}$, Ricardo S. Rosa ${ }^{3}$ \& Otto B. F. Gadig ${ }^{4}$
}

\begin{abstract}
The aim of this study is to report a scavenging event, involving the consumption of a nurse shark, Ginglymostoma cirratum, by tiger sharks, Galeocerdo cuvier, at Fernando de Noronha archipelago, Brazil. Recreational divers found and photographed a bitten nurse shark carcass, just after sighting two tiger sharks near of the site. We estimated the sharks total lengths and discussed aspects of this feeding interaction using of images of forensic analysis. A straight cut on the nurse shark caudal fin, whose total length was estimated as $200 \mathrm{~cm}$, suggest that it was caught by illegal fishing. A skin peeling process on the nurse shark fins indicates that the tiger sharks consumed it after its death, in a scavenging event. This is the first published report of a scavenging event involving the consumption of an elasmobranch by tiger sharks, allowing a better comprehension of tiger sharks' alimentary biology.
\end{abstract}

Keywords: Carcharhinidae; Ginglymostoma; scavenging behavior; forensic analysis; Fernando de Noronha archipelago; Brazil

Edited by Juan Carlos Salcedo-Reyes $\bowtie$ \& Andrés Felipe Navia

1. Programa de Pós Graduação em Ciências Biológicas, CCEN,

Universidade Federal da Paraíba, João Pessoa, Paraíba, Brazil.

2 Florida Museum of Natural History University of Florida,

Gainesville, Florida, U.S.A.

3 Departamento de Sistemática e Ecologia, CCEN, Universidade

Federal da Paraíba, João Pessoa, Paraíba, Brazil.

4 Laboratório de Pesquisa em Elasmobrânquios e Nécton Marinho, UNESP, São Vicente, São Paulo, Brazil.

Received: 02-12-2014 Accepted: 25-06-2015

Published on line: 25-08-2015

Citation: Rada DP, Burgess GH, Rosa RS, Nunes e Silva LP \& Gadig OB (2015) Necrophagy of a nurse shark (Ginglymostoma cirratum) by tiger sharks (Galeocerdo cuvier). Universitas Scientiarum 20(3): 313-320

doi: 10.11144/Javeriana.SC20-3.noan

Funding: This study was funded by grants from CNPq.

Electronic supplementary material: Suppl. 1 video \& Suppl. 2

\section{Introduction}

Many studies on predatory and/or scavenging behavior of large sharks are based on the analysis of bites and teeth marks left on dead floating or washed ashore cetacean and turtle's carcasses (Bornatowski et al. 2012a) or on behavioral observations of white sharks, Carcharodon carcharias (Linnaeus, 1758) and tiger sharks, Galeocerdo cuvier (Peron \& LeSueur, 1822) feeding on cetacean carcasses (e.g. Bornatowski et al. 2012b, Taylor et al. 2012, Clua et al. 2013, Fallows et al. 2013). Studies focusing on interspecific or intraspecific elasmobranchs' feeding interactions are scarce, and the behavioral and kinematic aspects of this feeding activity remain almost unknown. 
The tiger shark has a circumglobal distribution mainly in tropical and subtropical coastal areas (Compagno 1984) and may reach body size up to $610 \mathrm{~cm}$ total length, TL (Castro 2011). The species is anatomically adapted for consuming large preys (Castro 2011). Several studies on the feeding habits of this species show a highly diverse diet, including preys such as invertebrates (mollusks, crustaceans), teleost fishes, other elasmobranchs, tetrapods (turtles, snakes, birds and mammals), as well as the ingestion of man-made objects (Randall 1992, Simpfendorfer 1992, Lowe et al. 1996, Heithaus 2001, Simpfendorfer et al. 2001, Ménard et al. 2013). Nonetheless, feeding studies based on the examination of stomach contents fail to discriminate whether such diet items are obtained through active predation or scavenging behavior. Although tiger sharks are known to consume dead vertebrates, both of marine and terrestrial origin, there are few published accounts of scavenging behavior by this species as compared to the number of diet studies (Gallagher et al. 2011) and no reports of the consumption of dead elasmobranchs by this species.

The tiger shark is recorded all along the Brazilian coast, especially in the northeastern coast, an area where some recent shark attacks on humans have been attributed to it (Gadig \& Sazima 2003).

In Brazil, data on the feeding behavior of this species are virtually unknown, with only five papers focusing exclusively on tiger shark feeding habits (Rosas et al. 1992, Gasparini \& Sazima 1995, Di Beneditto 2004, Shibuya et al. 2005, Bornatowski et al. 2007). In addition Gadig (unpublished data) found three elasmobranch species in tiger shark stomachs in Northeast Brazil, two batoids (Urotrygon sp. and Dasyatis sp.) and one small shark (Mustelus sp.). Gadig (pers. communication) also reported an opportunistic attack of a tiger shark on a hooked specimen of Carcharbinus porosus (Ranzani, 1839).

The present paper reports the consumption of a nurse shark, Ginglymostoma cirratum (Bonnaterre, 1788), by $G$. cuvier at the Fernando de Noronha archipelago, northeastern Brazil, and points out that the event represented a scavenging behavior, against the alternative explanation of active predation.

\section{Material and methods}

The evidences of this feeding event were based on the forensic analysis of underwater images provided by one of the divers (C. Rezende), as well on the report of the visual observations of another diver (J. T. Oliveira). Underwater images included a $35 \mathrm{~s}$ digital video showing the nurse shark carcass (available in Suppl. 1), two digital photographs of the tiger sharks and 13 of the nurse shark carcass.

The dive occurred on the afternoon of December 18, 2009, at the locality named "Pedras Secas I" (3 51'00.88” S / 32 22'24.45" W), in the Marine National Park of Fernando de Noronha, Brazil.

The analysis of the photographs aimed at three specific objectives: (1) confirming taxonomic identity of the species involved in the feeding event; (2) estimating the total length both of the nurse and tiger sharks, and (3) obtaining forensic evidence on the cause of the nurse shark's death and on the time elapsed from its death to the finding of the carcass.

The estimation of the nurse shark total length (TL) was based on body measurements (preorbital length and predorsal 1 length) made on two digital photographs of the carcass with the tpsDig program, Version 2.16 (Rohlf 2010). Body measurements were compared with adjacent photographed diving gear of known size (dial diameter of Suunto Mosquito diving computer), as well as with the proportional body measurements $(\% \mathrm{TL})$ given in the literature (Bigelow \& Schroeder 1948) and taken on one $64.8 \mathrm{~cm}$ TL male specimen of G. cirratum, preserved at the Universidade Federal da Paraíba ichthyological collection (UFPB 1972).

The tiger shark TL was estimated using the upper jaw circumference in the algorithm provided by Lowry et al. (2009). The upper jaw circumference was measured on a photograph showing a complete bite on the nurse shark carcass, using the tpsDig2 program and the diving computer dial diameter as a scale. The absence of objects of known size in the available tiger shark photos precluded direct comparative measurements on them, but aided to corroborate the total length estimation, by comparing the individual with the known ontogenetic changes in the species color pattern (Bigelow \& Schroeder 1948, Compagno 1984). 


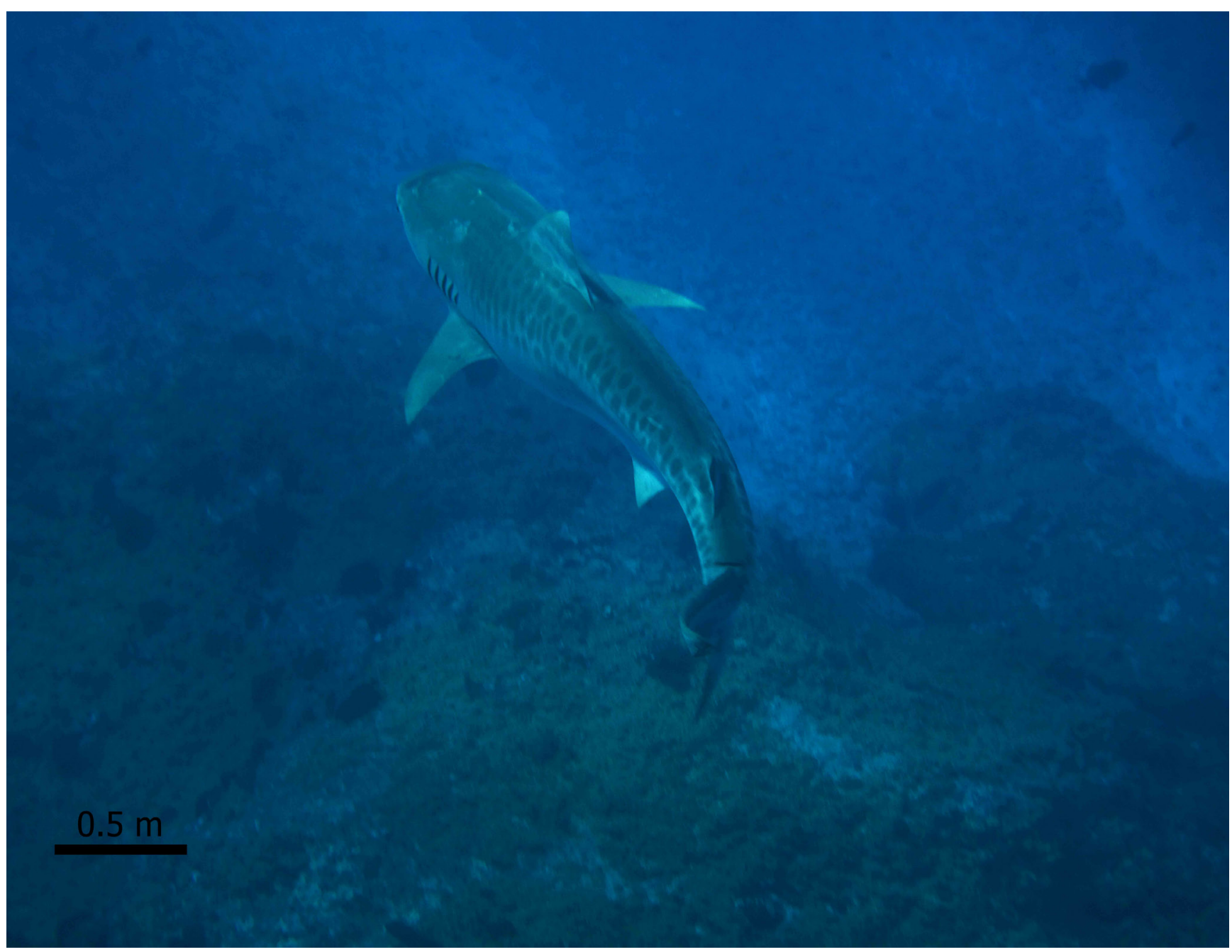

Fig. 1. A tiger shark (Galeocerdo cuvier) photographed at "Pedras Secas I", exiting the place where the nurse shark (Ginglymostoma cirratum) carcass was found by divers on December 18, 2009.

\section{Results and discussion}

The divers sighted two tiger sharks and one of them was photographed (Figure 1), representing a subadult or a small adult individual (sex not visualized in photos). The photographed tiger shark showed incompletely fused dark bars in flanks (as in adults) and lacked the mottled appearance found in juveniles up to $180 \mathrm{~cm}$ TL (Castro 2011). As soon as the divers reached the position previously occupied by the tiger sharks, they found, photographed and filmed a carcass of a female nurse shark lying on the rocky bottom (Figure 2). Neither the tiger sharks nor the carcass were collected, and the authors only had access to the digital images.
Some of the nurse shark photos allowed us to distinguish at least one conspicuous and complete tiger shark bite on the right flank of the anterior portion of the trunk. Its circumference measured 40.4 $\mathrm{cm}$ and led to the estimation of the tiger shark TL as $291.7 \mathrm{~cm}$, although it must be taken into account that total lengths obtained from bite circumferences usually are underestimated (Lowry et al. 2009). This is larger than the visually estimated TL reported by the divers, which ranged from 240 to $250 \mathrm{~cm}$, what suggests that the divers underestimated the $G$. cuvier TL or that a third unnoticed and larger individual of G. cuvier also consumed the carcass. The preorbital and first predorsal lengths of the nurse shark estimated from the photographs ranged from $11.4-18.0 \mathrm{~cm}$ 


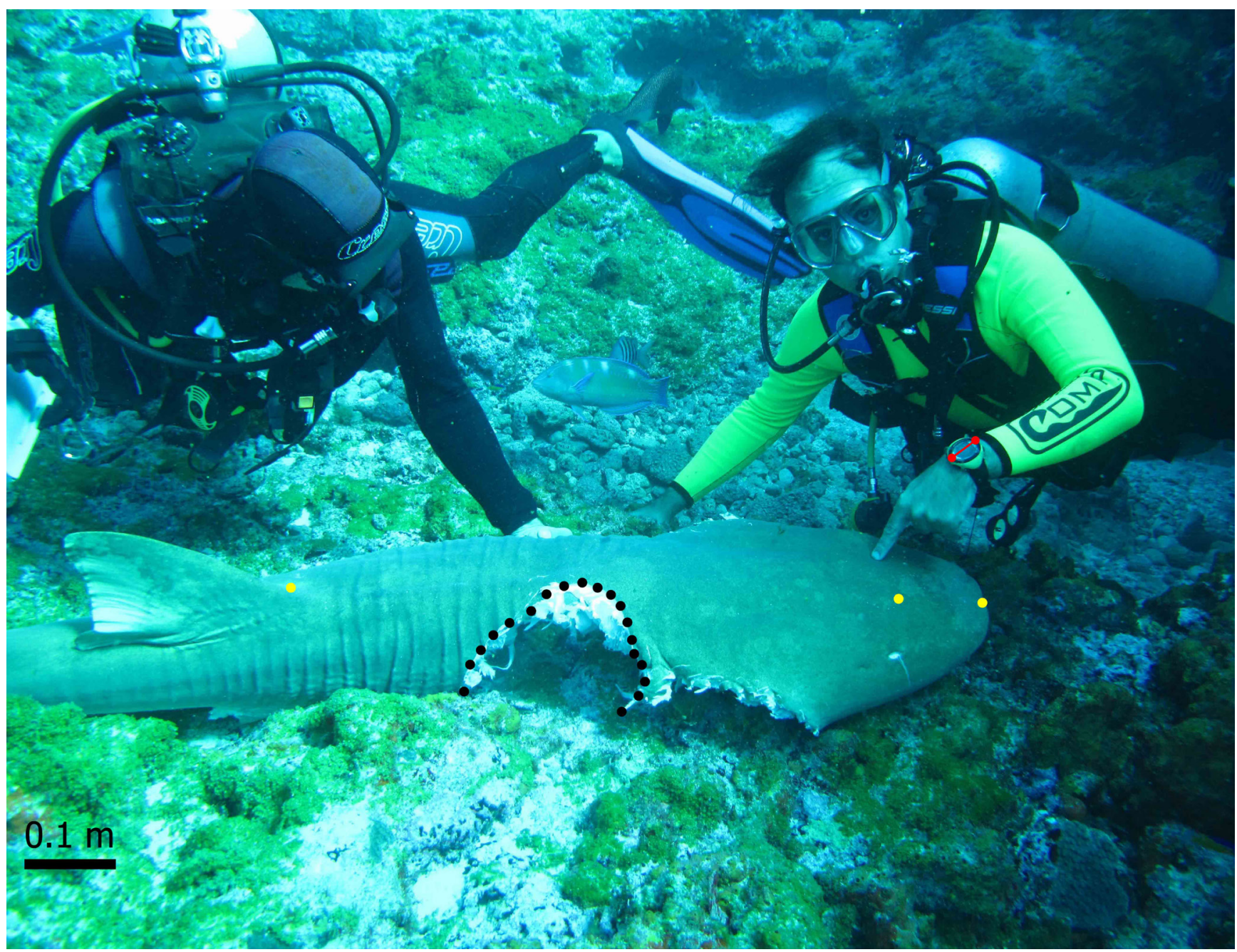

Fig. 2. The nurse shark (Ginglymostoma cirratum) carcass, showing the skin peeling process at the trailing edges of the dorsal fin and the landmarks used to estimate its total length (yellow dots) and to calculate the circumference of the tiger shark's (Galeocerdo cuvier) bite (black dots). The outer horizontal (W - E) diameter of the diving computer dial (red dots, $4.75 \mathrm{~cm}$ ) was used as a scale.

and $85.2-87.7 \mathrm{~cm}$, respectively. The preorbital length measured in specimens or given in the literature represented $6.93-7.70 \%$ TL, while the first predorsal length represented 41.9 - $42.4 \%$ TL. Back-calculated nurse shark total length ranged from 148.6 - 260.3 $\mathrm{cm}$ (mean $=202.0 \mathrm{~cm}, \mathrm{n}=4$ ) based on the obtained preorbital lengths, and from $201.0-209.2 \mathrm{~cm}$ (mean = $205.1 \mathrm{~cm}, \mathrm{n}=4$ ) based on the obtained first predorsal lenghts. These mean values did not grossly depart from the visually estimated total length reported by the divers, which ranged from 180 to $200 \mathrm{~cm}$. The missing caudal-fin upper lobe might be accounted for the slight difference.

Although the actual attack on the nurse shark body was not observed, the scavenging hypothesis is regarded as the more likely, as discussed below. Fishing is not permitted in the Fernando de Noronha Marine Park and therefore we assume that the nurse shark was not hooked at the moment of the attack by tiger sharks. In any event, illegal fishing occurs along the Brazilian coast (Santander-Neto et al. 2011) and thus, it is not an excluded possibility. A straight cut on the upper lobe of the caudal fin is seen in the video and in one of the examined photographs and suggests an artificially cut-off tail by a sharp instrument.

The various examined photographs show several lacerations by bites, distributed on both flanks and on the ventral portion of the trunk, and all organs of the abdominal and pericardial cavities removed (Figure 2). The upper caudal lobe, pectoral, and left 
pelvic fins are absent, but the anal fin and both dorsal fins are intact, exhibiting their posterior half margins clearly worn (Suppl. 2). The loss of scales and the irregular cropping of the trailing edges of these fins suggest that the nurse shark carcass had been visited by smaller fishes and/or invertebrates, indicating that a considerable time interval must have elapsed since the shark's death, thus rendering the necrophagy hypothesis more robust than the alternative active predation hypothesis.

The wound pattern herein observed - extensive and widely distributed irregular wounds in the nurse shark belly and flanks - suggests that the bites were made by more than one shark simultaneously. At a scavenging event reported in South Africa, five adult tiger sharks were observed feeding concurrently on a large cetacean carcass (Dudley et al. 2000). These authors suggested that ventral and lateral extensive bites (similar to those recorded here) indicate, respectively, twisting and swaying movements, a typical behavior described in concurrent scavenging activity by tiger sharks.

Although occurring sympatrically with several large tropical requiem and hammerhead sharks along its distribution range, the nurse shark is scarcely cited as prey of these species. Castro (2011) reports a 45 $\mathrm{cm}$ juvenile nurse shark from the stomach of a 234 $\mathrm{cm}$ lemon shark, Negaprion brevirostris (Poey, 1868) and commented on the underwater observation of the simultaneous pursuit of an adult nurse shark by Sphyrna mokarran (Rüppell, 1837) and Carcharbinus leucas (Valenciennes, 1839), where both sharks failed to attack and the potential prey evaded.

The extremely tough hide of the nurse shark and its habits of lying on the bottom and in crevasses (Garla et al. 2014), providing a greatly reduced field of approach by a predator, no doubt play key roles in this species' uncommon occurrence in the diets of sympatric predators. However, other elasmobranch fishes are frequently reported as tiger shark preys, but in lower numbers when compared with teleost fishes, marine mammals and reptiles (Simpfendorfer 1992, Lowe et al. 1996, Heithaus 2001, Simpfendorfer et al. 2001).

Some authors mentioned ontogenetic shifts in the diet of $G$. cuvier, in which larger preys are only consumed by medium or large sized individuals, linked to an ontogenetic improvement of hunting ability, use of different habitats and the enlargement of the jaws and mouth (Simpfendorfer 1992, Lowe et al. 1996, Simpfendorfer et al. 2001). The present observation indicates that tiger sharks about $300 \mathrm{~cm}$ TL are apt to consume large food items such as subadult nurse sharks. This mirrors the findings of Lowe et al. (1996), who pointed that elasmobranchs entered in the diet of tiger sharks above $200 \mathrm{~cm}$ TL size classes. Unfortunately, the feeding studies on G. cuvier do not allow to discern which and how many of these elasmobranch preys were consumed in predatory or scavenging attacks.

Several studies also pointed out that the diet of several elasmobranchs varies according to location, possibly reflecting prey availability (Cortés \& Gruber 1990, Lowe et al. 1996, Shibuya et al. 2005). Despite its status as "Near Threatened" in the Western Atlantic subpopulation (Rosa et al. 2006), G. cirratum still is relatively abundant in Fernando de Noronha, surpassed in numbers among sharks only by Carcharbinus perezi (Poey, 1876) (RC Garla pers. communication).

On the other hand, the tiger shark is not an abundant species in the area, with only sporadic records, and most data on this species in the tropical Brazilian coast referes to the continental shelf (Gadig 1994, Shibuya et al. 2005, Hazin et al. 2013). Thus, in spite of being considered as an energetic prey, G. cirratum probably does not suffer a high predation pressure by this large predatory shark at Fernando de Noronha archipelago, indicating that the necrophagy behavior reported here is an opportunistic event, with low energetic costs associated to it.

In Brazil, the scarcity of data regarding feeding interactions involving $G$. cuvier may be related either to the low investigation level of the feeding aspects of the species, or to the rare and opportunistic nature of such observations. According to Aguiar \& Valentin (2010), studies focusing on the feeding biology and ecology of Brazilian elasmobranchs, including grey literature, are restricted to only $26 \%$ of the species known to occur in the country.

As a concluding remark, we emphasize the importance of further studies on the feeding biology and ecology of elasmobranchs, particularly of top 
predators which directly affect lower trophic levels and the structuring and functioning of aquatic ecosystems. Furthermore, a detailed knowledge on the biology of elasmobranchs is necessary to the adequate management of these highly exploited and often overfished species.

\section{Conclusion}

This paper reports the consumption of an adult nurse shark, Ginglymostoma cirratum, by two or more adult tiger sharks, Galeocerdo cuvier, at Fernando de Noronha archipelago. Although this event was not completely observed, photographs demonstrate that the attacked carcass had initial signs of decomposition, like skin peeling all around the body, with more pronounced signals around the snout and on the posterior margins of both dorsal and anal fins. It suggests that the nurse shark was consumed post-mortem, in a scavenging event. It is known that tiger sharks prey other elasmobranchs, but this is the first published report of tiger sharks consuming another shark by scavenging. Scavenging reports involving tiger sharks are generally related to opportunistic occasions, including highly energetic items like cetaceans, turtles and, in this case, a nurse shark. This report helps to elucidate tiger sharks' alimentary biology aspects, especially in the southwestern Atlantic populations, where scientific research on this subject is relatively scarce.

\section{Acknowledgements}

We thank Cláudio Rezende for the underwater images and José Tadeu de Oliveira for the information regarding the dive and the sharks' encounter. We also thank ICMBio for the accommodations and for the permits to develop elasmobranch research at the Fernando de Noronha archipelago. Roberto E. Reis for assisted us with the measurements on the tpsDig2 program. Rodrigo L. Moura and Marcelo Szpilman provided measurements of the diving computer. Ricardo S. Rosa and Otto B. F. Gadig's elasmobranch studies are funded by grants from $\mathrm{CNPq}$ (Proc. 309879/2013-2 for RSR and 304600/2012-1 for OBFG).

\section{Conflicts of interest}

The authors declare no conflicts of interest.

\section{References}

Aguiar AA, Valentin JL (2010) Biologia e ecologia alimentar de elasmobrânquios (Chondrichthyes: Elasmobranchii): uma revisão dos métodos e do estado da arte no Brasil. Oecologia Australis 14(2):464-489 doi: 10.4257/ oeco.2010.1402.09

Bigelow HB, Schroeder WC (1948) Sharks. In: Tee-Van J, Breder CM, Hildebrand SF, Parr AE, Schroeder WC (ed) Fishes of the Western North Atlantic. Sears Foundation for Marine Research, Yale University Press, New Haven, USA, pp 59-546

Bornatowski H, Robert MC, Costa L (2007) Dados sobre a alimentação de jovens de tubarão tigre, Galeocerdo cwiver (Péron \& Lesueur) (Elasmobranchii, Carcharhinidae), do sul do Brasil. Pan-American Journal of Aquatic Sciences 2(3):10-13

Bornatowski H, Heithaus MR, Batista CMP, Mascarenhas $\mathrm{R}$ (2012a) Shark scavenging and predation on sea turtles in northeastern Brazil. Amphibia-Reptilia 33:495-502 doi: 10.1163/15685381-00002852

Bornatowski H, Wedekin LL, Heithaus MR, Marcondes MCC, Rossi-Santos MR (2012b) Shark scavenging and predation on cetaceans at Abrolhos Bank, eastern Brazil. Journal of the Marine Biological Association of the United Kingdom 92(8):1767-1772 doi: 10.1017/ S0025315412001154

Castro J (2011) The Sharks of North America. Oxford University Press, New York, USA

CluaE,ChauvetC,ReadTC, WerryJ,LeeJ (2013)Behavioural patterns of a Tiger Shark (Galeocerdo cuvier) feeding aggregation at a blue whale carcass in Prony bay, New Caledonia. Marine and Freshwater Behaviour and Physiology 46(1):1-20 doi: 10.1080/10236244.2013.773127

Compagno LJV (1984) Sharks of the world. An annotated and illustrated catalogue of shark species known to date. Vol. 4. Part 2. Carcharhiniformes. FAO, Rome, Italy

Cortés E, Gruber SH (1990) Diet, Feeding Habits and Estimates of Daily Ration of Young Lemon Sharks, Negaprion brevirostris (Poey). Copeia 1:204-218 doi: $10.2307 / 1445836$

Di Beneditto AP (2004) Presence of Franciscana Dolphin (Pontoporia blainviller) remains in the stomach of a tiger shark (Galeocerdo cuvier) captured in Southeastern Brazil. Aquatic Mammals 30:311-314

Dudley SFJ, Anderson-Reade MD, Thompson GS, McMullen PB (2000) Concurrent scavenging off a whale carcass by great white sharks, Carcharodon carcharias, and tiger sharks, Galeocerdo cwiver. Fishery Bulletin 98:646-649 
Fallows C, Gallagher AJ, Hammerschlag N (2013) White sharks (Carcharodon carcharias) scavenging on whales and its potential role in further shaping the ecology of an apex predator. PLoS One 8:e60797 doi: 10.1371/ journal.pone.0060797

Gadig OBF (1994) Fauna de tubarões da costa Norte/ Nordeste do Brasil (Chondrichthyes: Elasmobranchii). Master thesis, Universidade Federal da Paraíba, Brazil

Gadig OBF, Sazima I (2003) A non-fatal attack by the tiger shark, Galeocerdo cuvier, on the Northeast coast of Brazil (Chondrichthyes: Carcharhinidae). Arquivos de Ciências do Mar 36:119-122

Gallagher AJ,Jackson T, HammerschlagN (2011) Occurrence of tiger shark (Galeocerdo cuvier) scavenging on avian prey and its possible connection to large-scale bird die-offs in the Florida Keys. Florida Scientist 74(4):264-269

Garla RC, Garrone-Neto D, Gadig OBF (2014) Defensive strategies of neonate nurse sharks, Ginglymostoma cirratum, in an oceanic archipelago of the Western Central Atlantic. Acta Ethologica doi: 10.1007/s10211-014-0200-x

GaspariniJL, Sazima I (1995) Eretmochelys imbricata (hawksbill) predation. The Journal Herpetological Review 26(1):34

Hazin FHV, Afonso AS, Castilho PC, Ferreira LC, Rocha BCLM (2013) Regional movements of the tiger shark, Galeocerdo cuvier, off northeastern Brazil: inferences regarding shark attack hazard. Anais da Academia Brasileira de Ciências 85(3):1053-1062 doi: 10.1590/ S0001-37652013005000055

Heithaus MR (2001) The biology of tiger sharks, Galeocerdo cuvier, in Shark Bay, Western Australia: sex ratio, size distribution, diet, and seasonal changes in catch rates. Environmental Biology of Fishes 61:25-36 doi: 10.1023/A:1011021210685

Lowe CJ, Wetherbee BM, Crow GL, Tester AL (1996) Ontogenetic dietary shifts and feeding behaviour of the tiger shark, Galeocerdo cuvier, in Hawaiian waters. Environmental Biology of Fishes 47:203-211 doi: 10.1007/ BF00005044

Lowry D, Castro ALF, Mara K, Whitenack LB, Delius B et al. (2009) Determining shark size from forensic analysis of bite damage. Marine Biology 156:2483-2492 doi: $10.1007 / \mathrm{s} 00227-009-1273-3$

Ménard F, Potier M, Jaquemet S, Romanov E, Sebatié $\mathrm{R}$ et al. (2013) Pelagic cephalopods in the western Indian Ocean: New information from diets of top predators. Deep Sea Research II 95:83-92 doi: 10.1016/j. dsr2.2012.08.022

Randall JE (1992) Review of the biology of the tiger shark (Galeocerdo cuvier). Australian Journal of Marine \& Freshwater Research 43:21-31 doi: 10.1071/MF9920021
Rohlf FJ (2010) tpsDig version 2.1. http://life.bio.sunysb. edu/morph/. Retrieved April 152015

Rosa RS, Castro ALF, Furtado M, Monzini J, Grubbs RD (2006) Ginglymostoma cirratum (Western Atlantic subpopulation). www.iucnredlist.org. Retrieved November 132014

Rosas FCW, Capistrano LC, Di Beneditto AP, Ramos R (1992) Hydrurga leptonyx recovered from the stomach of a tiger shark captured off the Rio de Janeiro coast, Brazil. Mammalia 56:153-155

Santander-Neto J, Shimozaki-Mendes RA, Silveira LM, Jucá-Queiróz B, Furtado-Neto MAA et al. (2011) Population structure of nurse sharks, Ginglymostoma cirratum (Orectolobiformes), caught off Ceará State, Brazil, south-western equatorial Atlantic. Journal of the Marine Biological Association of the United Kingdom 91(6):1193-1196 doi: 10.1017/S0025315410001293

Shibuya A, Rosa RS, Gadig OBF (2005) Stomach contents of Galeocerdo cuvieri and Carcharbinus plumbeus (Elasmobranchii: Carcharhinidae) caught off Paraíba state, Brazil. Arquivos de Ciências do Mar 38:105-107

Simpfendorfer CA (1992) Biology of tiger sharks (Galeocerdo cuvier) caught by the Queensland shark meshing program off Townsville, Australia. Australian Journal of Marine \& Freshwater Research 43:33-43 doi: 10.1071/MF9920033

Simpfendorfer CA, Goodreid AB, McAuley RB (2001) Size, sex and geographic variation in the diet of the tiger shark, Galeocerdo cuvier, from Western Australian waters. Environmental Biology of Fishes 61:37-46 doi: 10.1023/A:1011021710183

Taylor JKD, Mandelman JW, McLellan WA, Moore MJ, Skomal GB et al. (2012) Shark predation on North Atlantic right whales (Eubalaena glacialis) in the southeastern United States calving ground. Marine Mammal Science doi: 10.1111/j.1748-7692.2011.00542.x 
Necrofagia de un tiburón nodriza (Ginglymostoma cirratum) por tiburones tigre (Galeocerdo cuvier)

Resumen. El objetivo de este estudio es reportar un evento de necrofagia que involucra el consumo de un tiburón nodriza (Ginglymostoma cirratum) por tiburones tigre (Galeocerdo cwiver) en el archipiélago de Fernando de Noronha, Brazil. Buzos aficionados encontraron y fotografiaron los restos mordidos de un tiburón nodriza, justo después de ver a dos tiburones tigre cerca del lugar. Mediante el análisis forense de imágenes estimamos la longitud total de los tiburones, y discutimos aspectos de esta interacción alimenticia. Una cortada recta en la aleta caudal del tiburón nodriza, cuya longitud total se estimó en $200 \mathrm{~cm}$, sugiere que fue objeto de pesca ilegal. El desprendimiento de la piel observado en las aletas del tiburón nodriza indica que los tiburones tigre lo consumieron después de su muerte, en un evento de necrofagia. Este es el primer reporte publicado de un evento de necrofagia que involucra el consumo de un elasmobranquio por tiburones tigre, lo cual permite una mejor comprensión de su biología alimentaria.

Palabras clave: Carcharhinidae; Ginglymostoma; comportamiento alimentario; análisis forense; archipiélago de Fernando de Noronha; Brasil
Necrofagia de um tubaráo lixa (Ginglymostoma cirratum) por tubaróes tigre (Galeocerdo cuvier)

Resumo. O objetivo deste estudo é relatar um evento de necrofagia, envolvendo o consumo de um tubarão lixa, Ginglymostoma cirratum, por tubarões tigres, Galeocerdo cuvier, no arquipélago de Fernando de Noronha, Brasil. Mergulhadores recreativos encontraram e fotografaram uma carcaça de tubarão lixa com marcas de mordida, logo após avistarem dois tubarões tigres no mesmo local. A análise forense das imagens permitiu estimar o comprimento total dos tubarões, bem como discutir aspectos desta interação alimentar. Um corte reto na nadadeira caudal do tubarão lixa, cujo comprimento total foi estimado em $200 \mathrm{~cm}$, sugere que ele foi vítima da pesca ilegal. A descamação das nadadeiras indica que o tubarão lixa foi consumido pelos tubarões tigres depois de morto, em um evento de necrofagia. Este é o primeiro reporte publicado de necrofagia de um elasmobrânquio por tubarões tigres, contribuindo para a compreensão de sua biologia alimentar.

Palavras-chave: Carcharhinidae; Ginglymostoma; comportamento alimentar; análise forense; arquipélago de Fernando de Noronha; Brasil 